\title{
Culinary diagnosis of traditional cuisine in the state of hidalgo
}

\author{
Diagnóstico culinario de las cocinas tradicionales en el estado de Hidalgo
}

\author{
José A. Carrillo-Silvano ${ }^{a}$ Laura de Guadalupe. Vázquez-Paz ${ }^{b}$ Jair E. Onofre-Sánchez ${ }^{c}$
}

\begin{abstract}
:
The essence is the cultural and historical representation of the Mexican people and it lies in the markets, food inns, public squares but above all, in the stoves of the cooks and their families in the communities of our country, this is how the gastronomic culture of Hidalgo is not only represented by Pastes, exquisite barbecue from Actopan or the emblematic Pulque of pre-Hispanic origins. Based on ethnographic methodology, interaction was made with communities without incurring the daily activities of people. This methodology allows people from different municipalities to show the activities they do on a daily basis in their community, the cooks that participate were Ms. Porfiria Rodríguez, traditional cook of Santiago de Anaya, Ms. Cristina Martínez Cruz and Florentina, traditional mushroom collectors and cooks from the municipality of Acaxochitlán, in the town of Los Reyes, Mr. Mario Islas Palacio, of work Tlachiquero, among others, are the ones who allowed to know the traditional gastronomy. As the final phase the information processing was carried out, so the present work has as a first term to describe the current situation of the traditional cuisine of the state of Hidalgo and the transcendence that it has had in recent years.
\end{abstract}

\section{Keywords:}

Ethnography, communities, heritage, gastronomy

\section{Resumen:}

La esencia es la representación cultural e histórica de los pueblos mexicanos y yace en los mercados, fondas, plazas públicas, pero sobre todo en los fogones de las cocineras y sus familias en las comunidades de nuestro país, es así como la cultura gastronómica hidalguense no solo es representada por Pastes, exquisita barbacoa de Actopan o el emblemático Pulque de orígenes prehispánicos. Con base en la metodología etnográfica se interactuó con las comunidades sin incurrir en las actividades cotidianas de las personas. La aplicación de esta permite que personas de los diferentes municipios mostraran las actividades que realizan de forma cotidiana en su comunidad, siendo la Sra. Porfiria Rodríguez Cadena cocinera tradicional de Santiago de Anaya, las Sras. Cristina Martínez Cruz y Florentina Martínez Martínez recolectoras de hongos y cocineras tradicionales del municipio de Acaxochitlán, en la localidad de los Reyes, el Sr. Mario Islas Palacio de oficio tlachiquero entre otros, son quienes permitieron conocer la gastronomía tradicional. Como fase final se realizó el procesamiento de la información, por lo que el presente trabajo tiene como primer término describir la situación actual de las cocinas tradicionales del estado de Hidalgo y la trascendencia que ha tenido en los últimos años.

\section{Palabras Clave:}

Etnografía, comunidades, patrimonio, gastronomía

\section{Introduction}

From ancient Mexico to today's Mexico, great changes have been experienced, from the foundations to what we know nowadays, that is why the forerunners of our ancestors' legacy still keeping alive customs such as sowing, harvesting, breeding, hunting and even transforming these into a tasty, healthy and varied diet; due to the great immersion in the new gastronomic trends, we take for granted that traditional cuisine is the basis on which, proposals have been created to achieve a level of

\footnotetext{
a Licenciado en Gastronomía, Universidad Tecnológica de Cancún, División de Gastronomía, https://orcid.org/0000-0001-7700-2248, Email: silvano9629@gmail.com

b Profesor investigador Universidad Tecnológica de Cancún, División de Gastronomía, https://orcid.org/0000-0003-0614-5676, Email: lvazquez@utcancun.edu.mx

c Autor de Correspondencia, Profesor investigador Universidad Autónoma del Estado de Hidalgo, Instituto de Ciencias Económico Administrativas. Programa educativo de Gastronomía, https://orcid.org/0000-0002-9484-8947, Email: jair_onofre6570@uaeh.edu.mx
} 
handling innovative techniques, also known as contemporary cuisine, that is the one offered in the restaurants but is nothing more than a proposal of the cooks giving their personal touch or sometimes completely changing the characteristics of the native dish of the place, causing the visitors to perceive it as traditional. This work aims to show features of the traditional cuisine of the state of Hidalgo, through an exploratory research with eth nographic focus in the towns of Hidalgo.

Since the designation of our gastronomy as an intangible cultural heritage of humanity by UNESCO in 2010, we consider that if this ancestral knowledge is not written in a document, and if it is not transmitted through education to new generations, and disseminated through publications, it would certainly be lost, that is why this research aims to describe the food customs existing in different towns of Hidalgo, knowing those activities that through culture and tradition are still kept alive, to promote and preserve through documentation the way of life of traditional cooks and their families.

\section{Justification}

Talking about the state of Hidalgo is to talk about a present ethnic plurality in all the corners of the state, its native languages Otomí, Nahuas and Tepehua are part of its cultural richness, to document this would be appropriate as it represents part of our country's cultural heritage, it is suitable for a true vision of our ancient Mexico and it would contribute to generate knowledge and information for the development of various fields, including science, tourism and the socio-economic development of communities, in order to improve the perspective of a culinary culture.

In the geographic regions of Hidalgo, ancestral culinary knowledge is kept; therefore, it is convenient to document these methods, techniques, ingredients, festivities and even the culinary language that is used in different communities to promote and preserve the gastronomic culture.

In order to document the gastronomic culture of Hidalgo, the regions established in the state according to its geography have been taken as reference, where the different cultural expressions allow us to know representative dishes, local products, current traditions, culinary techniques, kitchen items to mention a few.

To preserve the gastronomic culture depends on those whose knowledge of the traditions, techniques and customs that were transmitted and so, the new generations reinforce it and keep it alive, time changes and adapting without losing the essence will allow inheritors of the culture to know and extent the traditional Mexican cuisine.

\section{Problem Statement}

Nowadays the villages of Hidalgo do not have a gastronomic bibliography because it is not widely studied, and the prevailing need to transmit the gastronomic culture of the state has resulted in this research. The lives of Hidalgo families far from the big cities have changed their food, largely due to external influence. This makes us to think more about the gastronomy of these people that still maintain their customs since ancient times. The aim of this study is to disseminate the cultural features of the different communities of the state, where its inhabitants are people of Otomí, Nahuas and Tepehuas origin, main protectors of the knowledge and flavors of the cuisine

\section{General Objective}

To describe the culinary culture existing in the rural communities of the state of Hidalgo that contribute to the preservation of the typical gastronomy to generate projects that foster their development and identity.

\section{Specific Objectives}

To identify through different sources (bibliographic, hemerographic, chronicler among others) the culinary background of Hidalgo to strengthen the information.

To identify key informants in the area that allow direct contact with their way of life for data collection.

To make fieldwork with data collection and instruments such as guided interview and observation guide.

To document the results obtained through the different data sources.

\section{Research Questions}

1. What is the culinary heritage existing in the villages of the state of Hidalgo (which includes the use of food products, processes and kitchen items)?

2. What are the main characteristics and eating habits of the people of Hidalgo?

3. What animal and plant products are used in indigenous communities?

4. What are the representative dishes of the villages? 


\section{Historical framework}

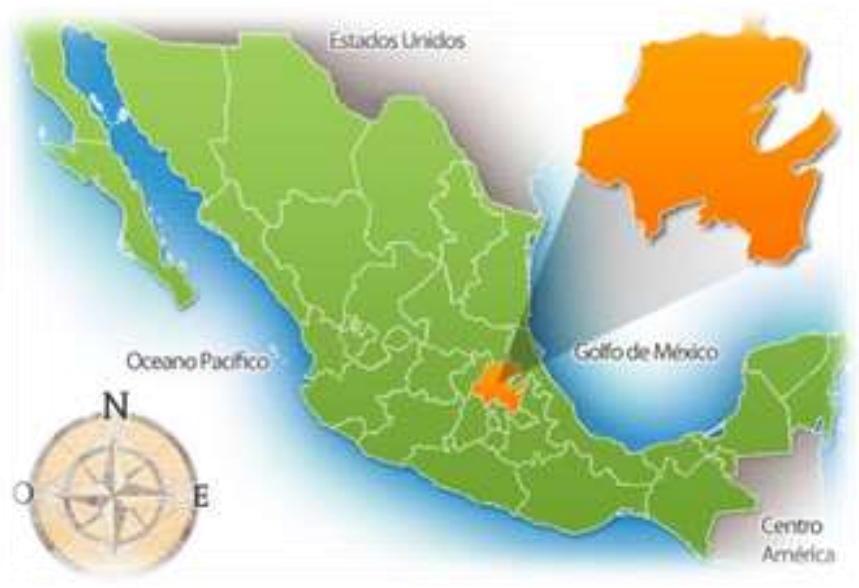

Illustration 1 Location of Hidalgo State, Source: http://mr.travelbymexico.com/692-estado-de-hidalgo/ http://mr.travelbymexico.com/692-estado-de-hidalgo/

The state of Hidalgo is located in the center of the country and borders the states of Mexico, Puebla, Querétaro, San Luis Potosí, Tlaxcala and Veracruz.

\section{Prehispanic Hidalgo}

Mexican history has shown that there are differentperiods in which great feats that we know today have been developed, one of them is during the pre-Hispanic period about 11,000 years ago, in what is today Hidalgo. (Contreras, 2017) in his article Historia de Hidalgo: Características más resaltantes, mentions that it is a territory with different indigenous ethnicities, being the Toltecas who founded the first villages of Xochicoatlán (now Molango) and Tula de Allende at the beginning of the seventh century settled in Huejutla and Tollatzingo (Tulancingo). Later the Chichimecas invade and found Meztitlán; later with the great increase of the Aztec empire they also invade them, founding Mixquiahuala, Tizayuca and Tepehuacán [1]

\section{Colonial Period}

During the intervention of the Spaniards to Mexico and the colonization of this, a new religion began to be imposed on the native Mexican people, new social relations and a system of production, with the birth of the "Haciendas" a form of economic organization; the first friars who came during evangelization left the churches and convents and were replaced by Catholic priests. Also in the early years of the colony in New Spain, silver and copper mines were discovered in Real del Monte and Pachuca, increasing the population in the area and the exploitation of minerals in which many men made large fortunes.
The first independent registration was found in Huichiapan with the first armed uprisings against the Spaniards who oppressed the villages, followed by Tula de Allende, Zimapan, Ixmiquilpan, Apan, Tulancingo, Pachuca, Zempoala, the Sierra Alta and the Huasteca. Although it is true that during this stage there were no great battles, the independence movement of 1810 led by the priest Hidalgo and José María helped a lot to the cause of independentist, so that 15 days after the cry of Dolores was given, the armed uprisings began in Hidalgo by Miguel Sánchez, Julián Villagrán and his son Jose María; on September 16, 1812 in Huichapan General Ignacio López Rayón the secretary of the priest Hidalgo and Andrés Quintana Roo gave for the first time the cry of independence [1]

With the independence movement the constitution of 1824 was promulgated, where the formation of the federal republic constituted by 19 states and 4 territories was decreed, Hidalgo remained as part of the state of Mexico, The state of Hidalgo was created on January 16, 1869, by decree of the union and then president Benito Juárez after a series of political considerations, owing his name to Don Miguel Hidalgo y Costilla. The capital of the state (Pachuca) is also known as "La Bella airosa" because strong northeast winds arrive there during eightmonth of the year [2]

\section{Contextual framework}

The UNESCO, (2011) defines intangible heritage as a traditional, contemporary and living activity, at the same time it includes not only traditions inherited from the past, but also contemporary rural and urban uses, characteristic of various cultural groups. Knowledge of the traditions, techniques and customs that are transmitted to the rest of humanity depends on this, contributing to the feeling of identity and continuity, creating a link between the past and the future through the present [3]

According to (Pizarro Hernández, et al., 2013) In the state of Hidalgo there are regions with a high indigenous population such as: the Huasteca, the Sierra and the municipality of Acaxochitlán with Nahua population, the Mezquital Valley with the Otomí or Hñahñu population and the Otomí Tepehua Mountains, namely the municipalities of Tenango de Doria, San Bartolo Tutotepec and Huehuetla with the Otomí and Tepehua populations. [4] A distinction granted by the Mexican Government to villages of the 32 federative entities is the name of "Pueblo Mágico" for unique characteristics such as geography, culture and history. According to [3] the state of Hidalgo has 5 pueblos mágicos, Real del Monte, Mineral del Chico, Huichapan, Tecozautla and Huasca de Ocampo being the first town in Mexico to receive this distinction in 2001.

Period of Independence 


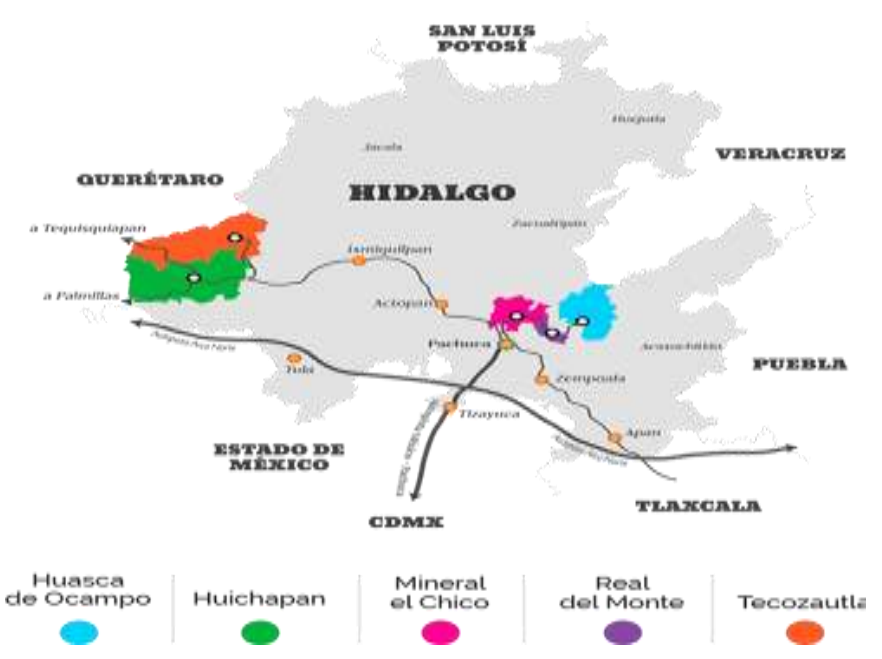

Illustration 2 Magic Villages, source:

http://hidalgo.travel/views/pueblos/Tecozautla/Tecozautl a.html

Another distinction that the state has is "pueblos con sabor", an initiative of the state government that through the secretary of tourism, evaluate and determine the applications obtained by the participating villages, the [5] and (Trejo, 2017) mention some points to be covered by applicants, two important points to mention would be the traditional preparation of the dishes, the production of an emblematic ingredient of the place among others. [6]

According to (Hernandez, 2018) the towns that obtained this distinction were Calnalli, Huejutla, Actopan, Omitlan, Zempoala, Acaxochitlán and Tulancingo with these distinctions it is expected to promote, and attract tourism to the state. [7]

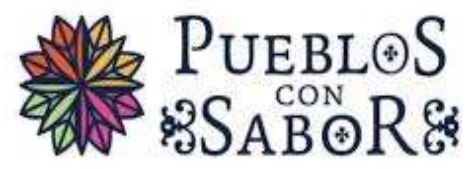

Illustration 3 Distinctive Villages with Flavor, source: http://turismo.hidalgo.gob.mx/pdf/BPUEBLOS CON SA BOR.pdf

\section{Method}

Based on the research objectives and ethnographic parameters where the description of the current situation in the traditional Hidalguense gastronomy, primary sources such as people from the localities were interviewed, to describe cooking techniques, the main ingredients used and the temporality of the most representative customs that have been lost over time that contribute to the research.
Ethnography that seeks the description and interpretation of the analyzed system, particularly the gastronomic culture, (Guerrero Arias, 2002) mentions that the ethnographic method refers to the description and analysis of daily activities, to understand the universes of meaning, the logics of the social action of others and of ourselves. Data collection was carried out through an observation guide and guided interview [8].

(Sánchez Martínez, 2014) mentions that the state of Hidalgo is represented by 10 geocultural regions, which serve as an object to develop this research, because each has its own geographical and cultural features, such as the Huasteca, Sierra Gorda, Sierra Alta, Sierra Baja, Sierra de Tenango, Valle de Tulancingo, Altiplanicie Pulquera, Comarca Minera, Cuenca de México and el Valle del Mezquital. [9]

\begin{tabular}{|c|c|c|c|}
\hline $\begin{array}{l}\text { PHASE } \\
\mathrm{S}\end{array}$ & $\begin{array}{ll}\text { WORK } & \text { TO } \\
\text { DEVELOP } & \end{array}$ & $\begin{array}{l}\text { APPLIED } \\
\text { INSTRUMENTS }\end{array}$ & $\begin{array}{l}\text { DATA PRESENTATION } \\
\text { AND MANAGEMENT }\end{array}$ \\
\hline $\begin{array}{l}\text { Phase } \\
\text { I }\end{array}$ & $\begin{array}{l}\text { To investigate } \\
\text { about existing } \\
\text { bibliographic } \\
\text { information to } \\
\text { support this } \\
\text { research. }\end{array}$ & $\begin{array}{l}\text { Selection and } \\
\text { classification of the } \\
\text { culinary bibliography } \\
\text { of Hidalgo. }\end{array}$ & $\begin{array}{l}\text { Qualitative data according } \\
\text { to the bibliographical } \\
\text { collection consulted. }\end{array}$ \\
\hline $\begin{array}{l}\text { Phase } \\
\text { II }\end{array}$ & $\begin{array}{l}\text { Design } \\
\text { instruments } \\
\text { gatherdata }\end{array}$ & $\begin{array}{l}\text { Guided questions } \\
\text { applied to the } \\
\text { community that is } \\
\text { being diagnosticated }\end{array}$ & $\begin{array}{l}\text { Qualitative data according } \\
\text { to the opinions of the } \\
\text { community. }\end{array}$ \\
\hline $\begin{array}{l}\text { Phase } \\
\text { III }\end{array}$ & \begin{tabular}{l} 
Identify the key \\
informants from \\
the culinary culture \\
of the state's \\
geographic \\
regions. - The \\
mountain range \\
(Tenango, Gorda, \\
Alta y Baja)- \\
Huasteca - Valles \\
(Mezquital and \\
Tulancingo) - \\
Altiplanicie \\
Pulquera \\
\multicolumn{1}{c}{-}
\end{tabular} & $\begin{array}{l}\text { An instrument of } \\
\text { guided questions } \\
\text { based on the main } \\
\text { aspects of culinary } \\
\text { culture applied to key } \\
\text { informants. }\end{array}$ & $\begin{array}{l}\text { Qualitative data that will be } \\
\text { presented according to the } \\
\text { background }\end{array}$ \\
\hline $\begin{array}{l}\text { Phase } \\
\text { IV }\end{array}$ & $\begin{array}{l}\text { To carry out field } \\
\text { work }\end{array}$ & Guiding questions & $\begin{array}{l}\text { Qualitative data to be } \\
\text { presented according to their } \\
\text { frequency. }\end{array}$ \\
\hline $\begin{array}{l}\text { Phase } \\
\text { V }\end{array}$ & $\begin{array}{l}\text { Interpretation of } \\
\text { results }\end{array}$ & $\begin{array}{l}\text { The results will be } \\
\text { organized according } \\
\text { to the diagnosed } \\
\text { regions and } \\
\text { communities. }\end{array}$ & $\begin{array}{l}\text { Qualitative data will be } \\
\text { presented by geocultural } \\
\text { region. }\end{array}$ \\
\hline
\end{tabular}

Table 1 Phases of the Methodology.

Because of its approach, this is a qualitative research, the collection of data was carried out through the technique of observation and by interviewing (see questions in Annexes 1) the cooks of the communities visited. The interviews were made with the support of guided questions with the purpose of documenting the local food culture, the information gathered makes it possible to know, safeguard and promote the identity of the communities of Hidalgo. Mexican cuisine is represented by customs and traditions that are more representative of the communities studied, ranging from planting and harvesting to the production of exquisite dishes. 


\section{Results}

During a period of three months, through the ethnographic method, a diagnosis of the traditional cuisine of Hidalgo was obtained, by visiting the municipalities to document the gastronomic information, through data collection strategies.

It is confirmed that nowadays, that the communities of the State of Hidalgo are integrated in different ways and with very different traits, on the other hand, gastronomy is one of the most important cultural manifestations of the indigenous people, with in thatterm there is a vast amount of information to be collected.

The following table shows the communities that were visited, as well as the cooks and a Tlachiquero that represent and serve as informants for the traditional gastronomy of the state.

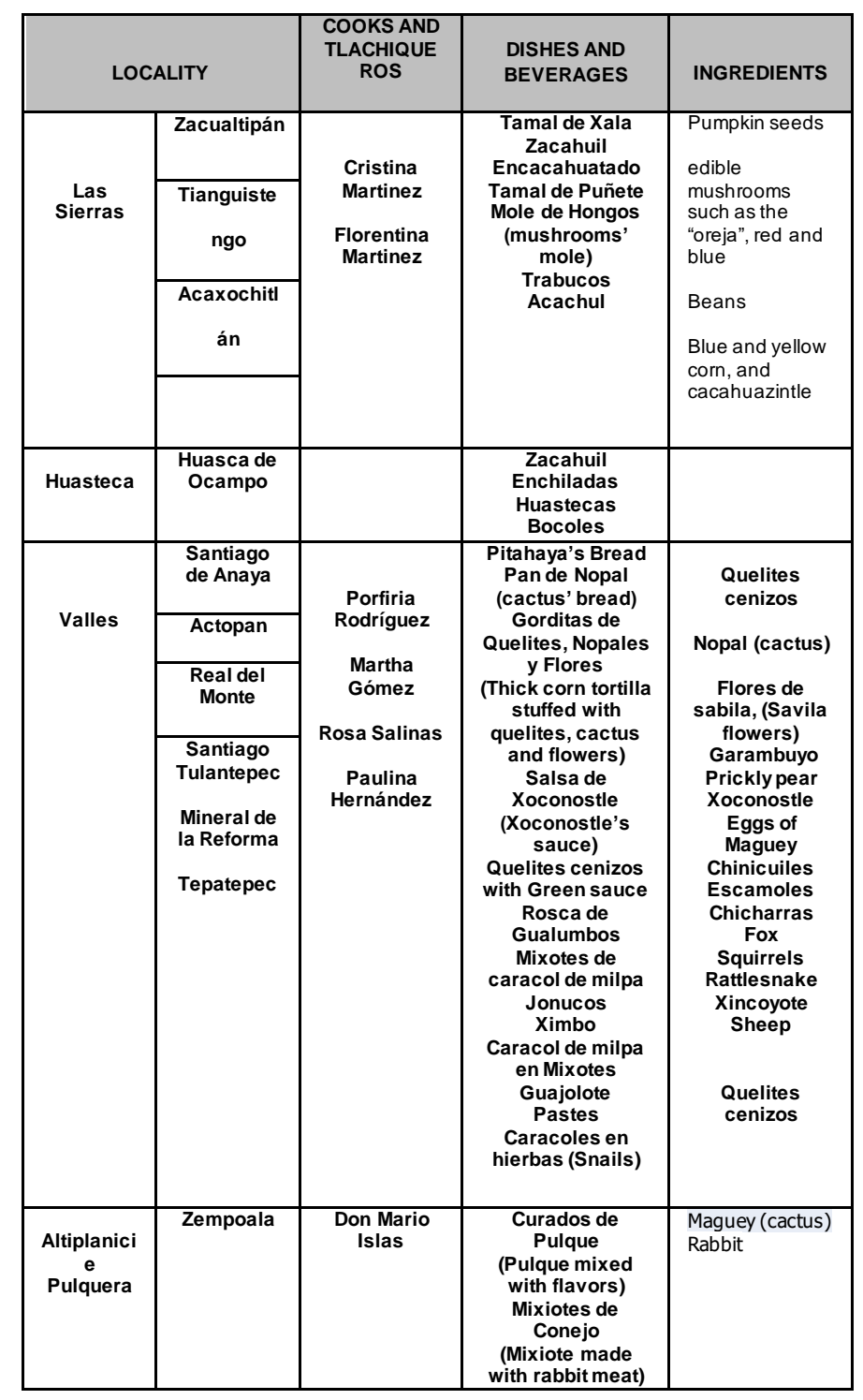

Table 2 Results of the culinary diagnosis of the traditional kitchens of Hidalgo. Written by: José Armando Carrillo Silvano.

The dishes and beverages described in the table are part of the traditions and ancestral food of the Otomís, Nahuas and Tepehuas communities of the region, having specific days for certain dishes that allow people to do their daily activities such as agriculture, the breeding and marketing of the products that represent the economic life of the cooks. Some dishes are still not cooked in the region, because the majority of the ingredients that are used to cook them are not produced anymore.

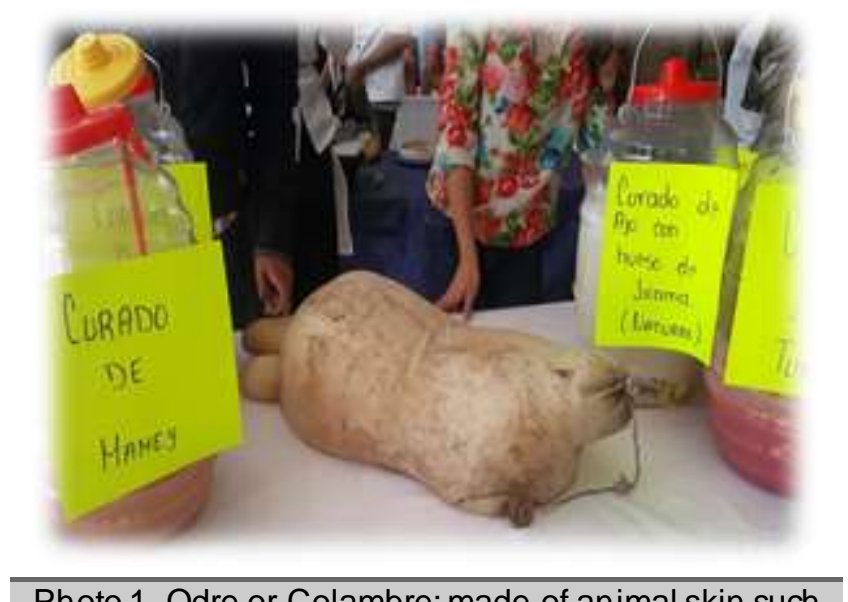

Photo 1. Odre or Colambre: made of animal skin such as sheep, which served as a container originally used for the transportation of pulque. In some communities that produce pulque in the state of Hidalgo is still used. Photograph by José Armando Carrillo Silvano, 2018.

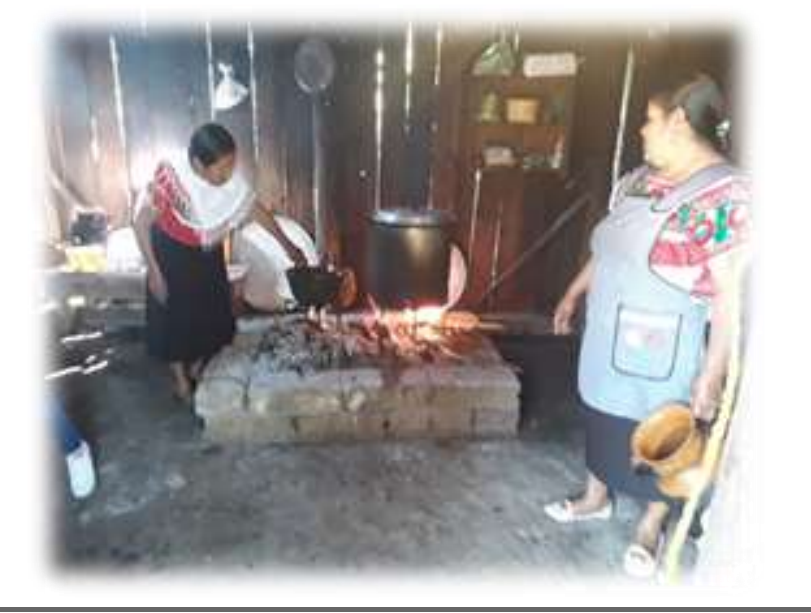


Photo 2 Nanakateras: Traditional cooks from Acaxochitlán, women of Nahua origin who collect edible mushrooms from the community of los Reyes.

Photograph by José Armando Carrillo Silvano, 2018.

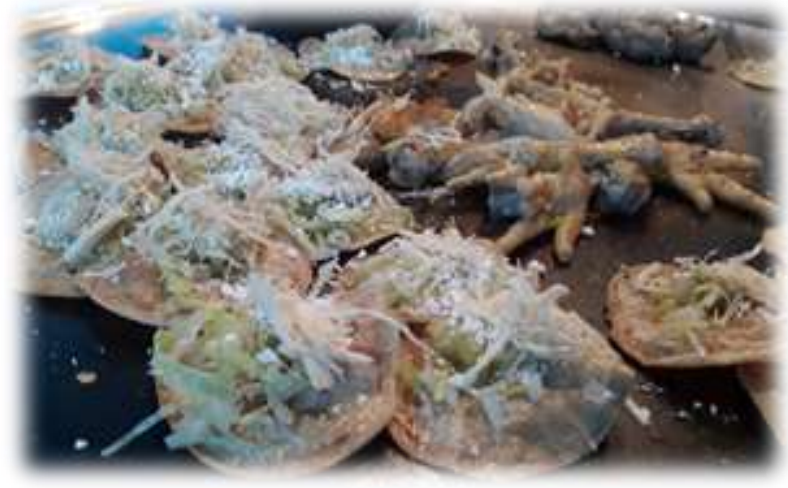

Photo 3 Chalupas and Patitas de Pollo: Street appetizers bathed in green sauce (salsa) and sometimes in red sauce, and lettuce, chicken and cheese, typical of street stalls and food inns of Pachuca and Real del Monte, that unlike the chalupas Poblanas, the chalupas Hidalguenses are made with small tortillas. On the other hand the patitas de pollo, the huacal, chicken gizzards, liver and heart, are fried in lard, they are part of exquisite street food dishes. Photograph by José Armando Carrillo Silvano, 2018.

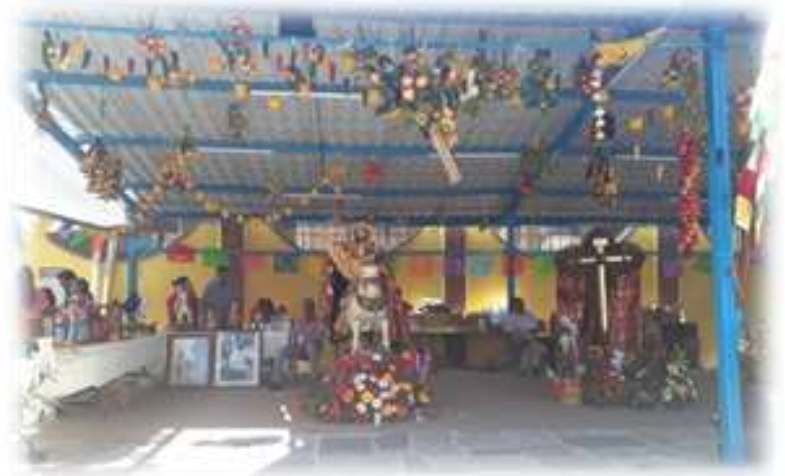

Photo 4 Santo Patrono Santiago Apóstol: Fruit Fair, held in Tecozautla, Hidalgo. Where the devotees decorate the church's atrium with different fruits, such as pomegranate and figs, banana, apples, and others; as a sign of gratitude for their harvests, those fruits are given to visitors after the end of the festivities. Photograph by José Armando Carrillo Silvano, 2018.

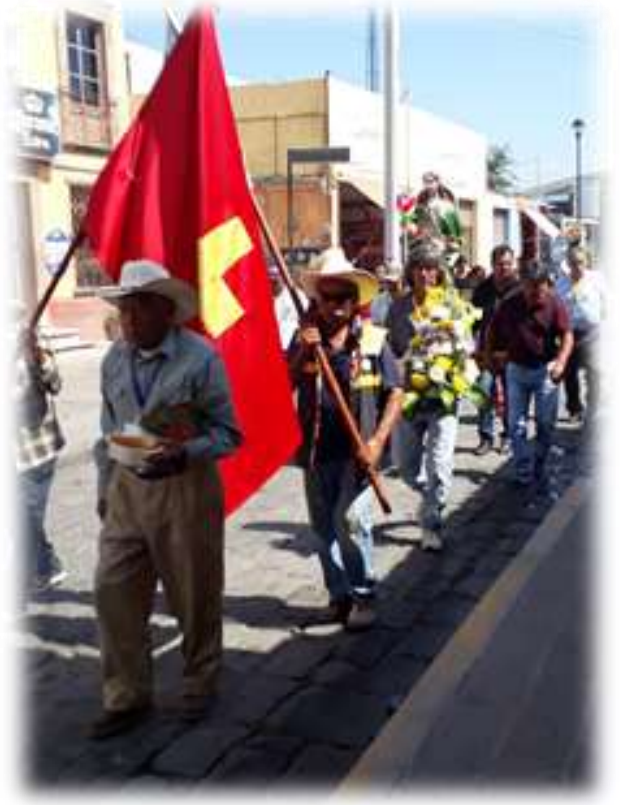

Photo 5 Procession of Santiago Apóstol: Following the belief that the Saint appeared on the hill of Sanabria, the devotees make this walk every year to the place, carrying the image of the saint. Photograph by José Armando Carrillo Silvano, 2018.

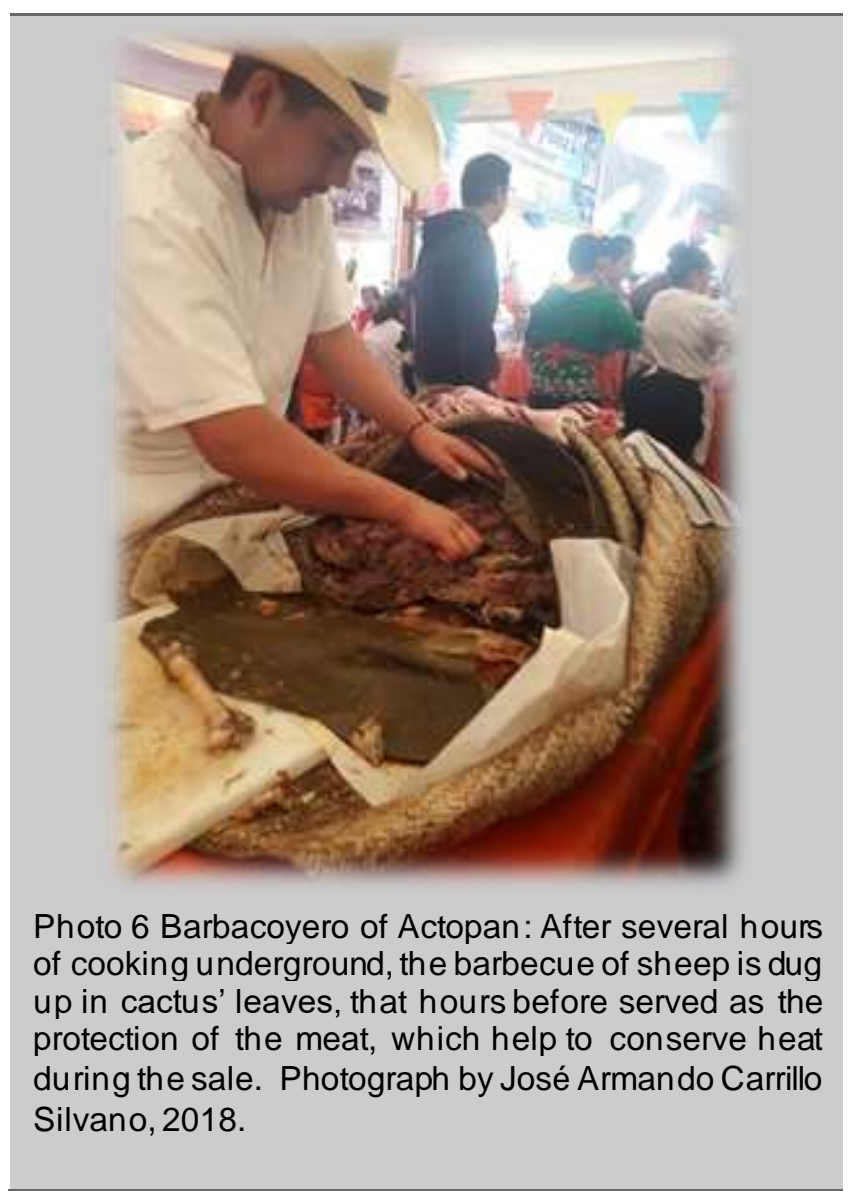




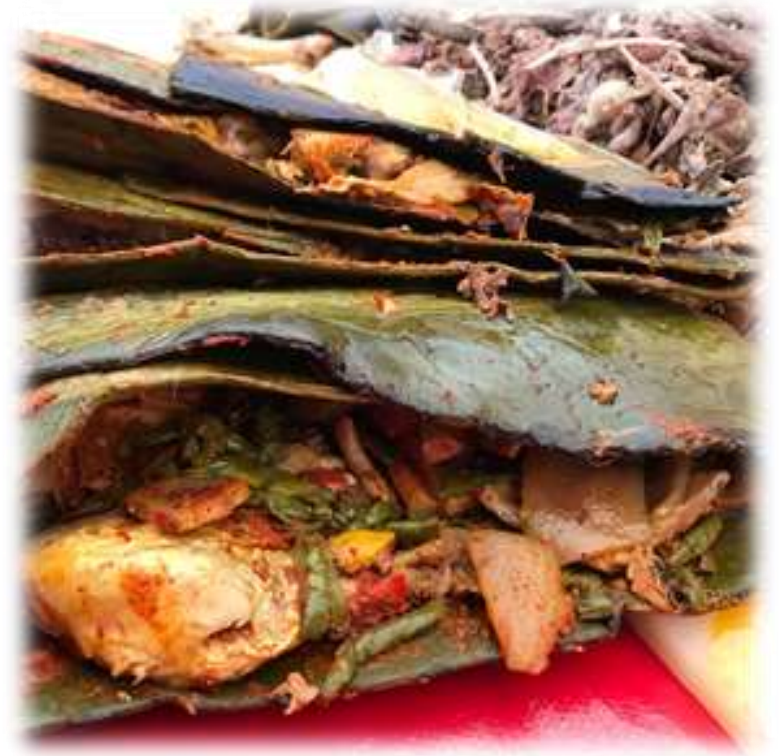

Photo 7 Ximbo: Typical dish of Actopan, Hidalgo. It is characterized by wrapping the meat in maguey's leaves and being steamed in an underground oven. The most popularximbos are made with chicken, pork, Chamorro and sometimes skunk. Photograph by Ixachi Cravioto Balderas, 2018.

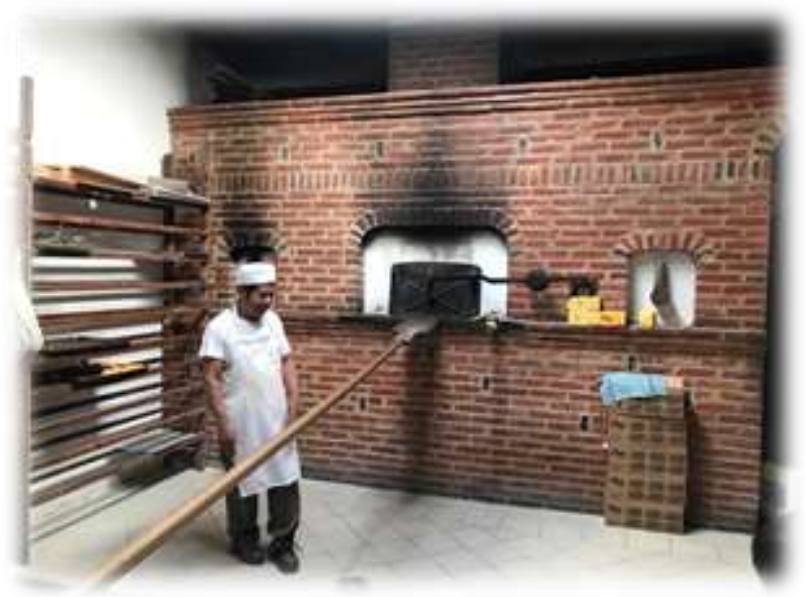

Photo 8 Traditional Oven of Pastes: Near the center of Pachuca, Hidalgo. There are the pastes LA PROVIDENCIA or better known as "Don Armando" pastes, a place where 15,000 pastes were once baked for Miguel de la Madrid. Photograph by Ixachi Cravioto Balderas, 2018.

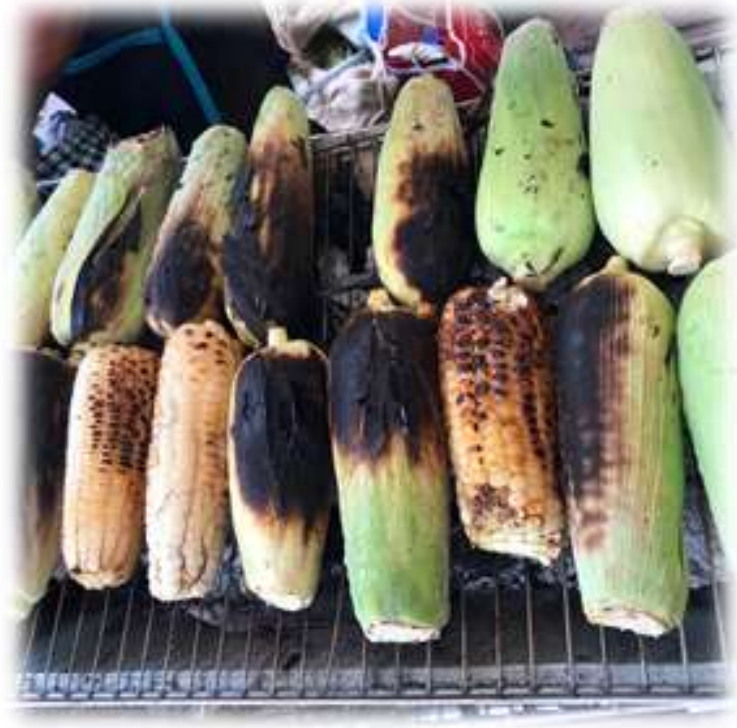

Photo 9 Cacahuazintle corn: Roasted cacahuazintle corn can be found in Valle del Mezquital and near the sierra. Photograph by Ixachi Cravioto Balderas, 2018.

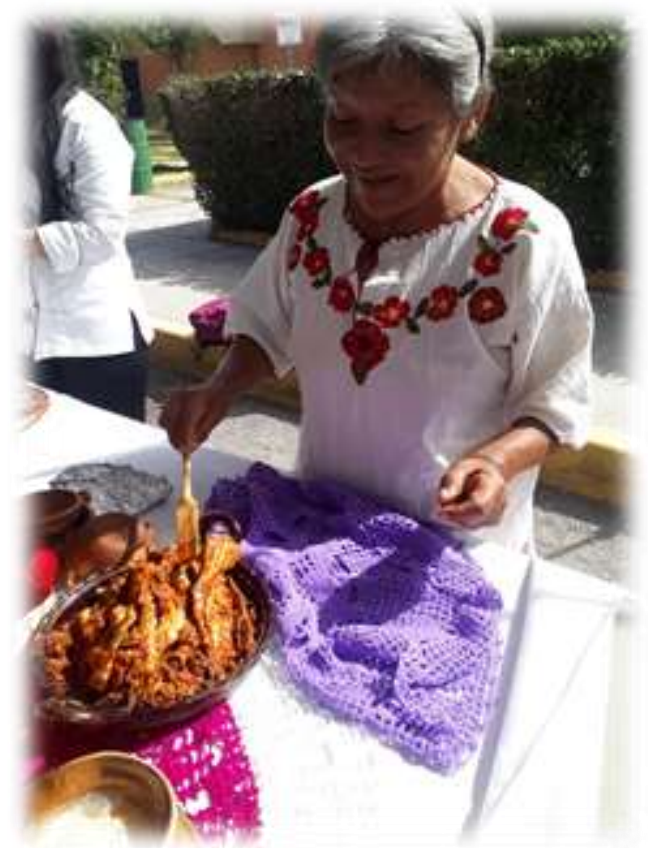

Photo 10 A cook from Valle del Mezquital: During the assignation as gastronomic pavilion of Actopan, Hidalgo, the traditional cook Paulina Hernández, from the community of La Palma, presents a dish that was inherited by her grandparents, chicken stuffed with milpa snails and mechal?. Photograph by José Armando Carrillo Silvano, 2018. 


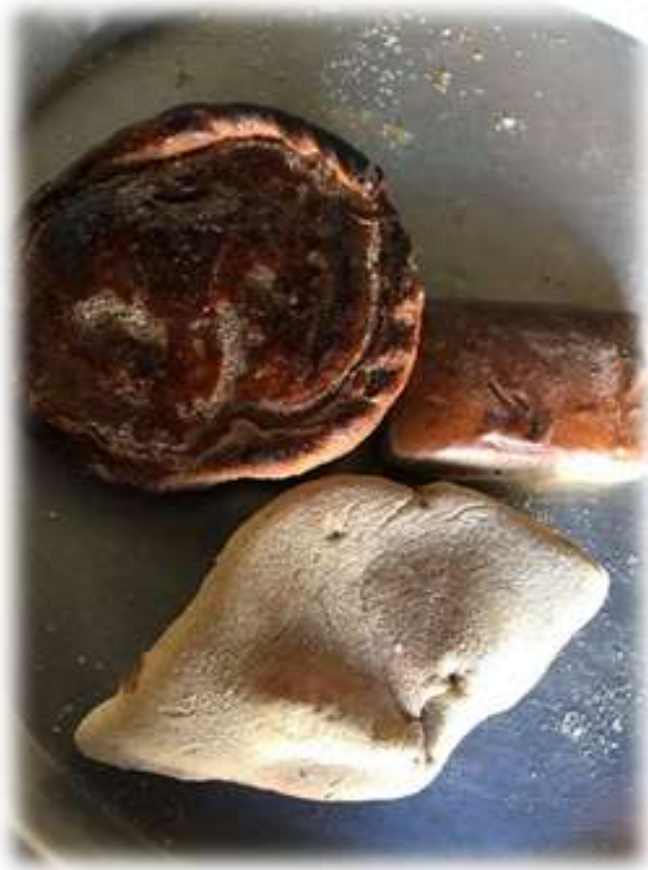

Photo 11 Traditional bakery in Zempoala: Photograph by Ixachi Cravioto Balderas, 2018.

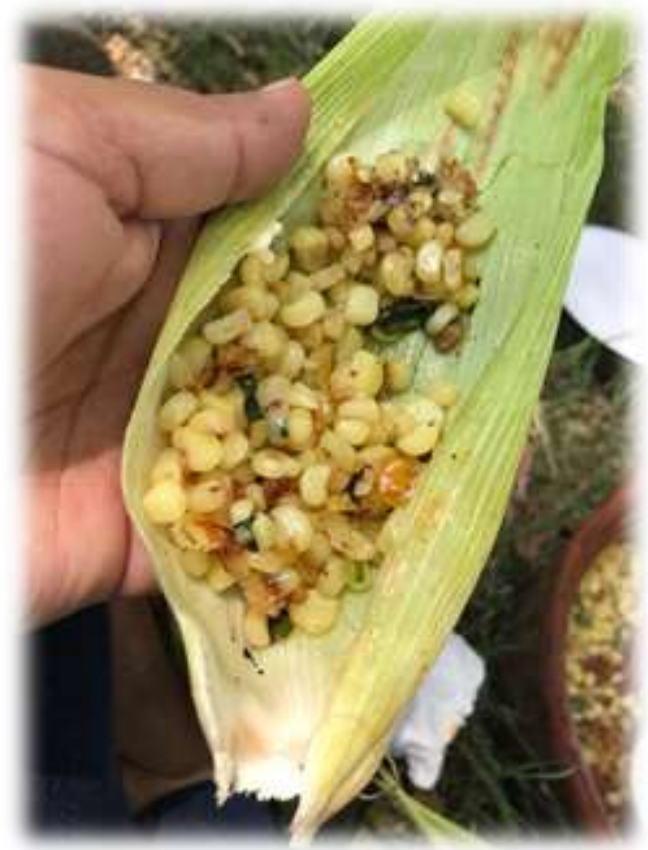

Photo 12 Esquites borrachitos (corn with alcohol): During the season of fresh corn, in the community of Tepatepec the farmers make various preparations based on this corn, highlighting a dish for its elaboration with pulque "los borrachitos". Cooked com with epazote, serrano pepper and pulque. Photograph by Ixachi Cravioto Balderas, 2018.

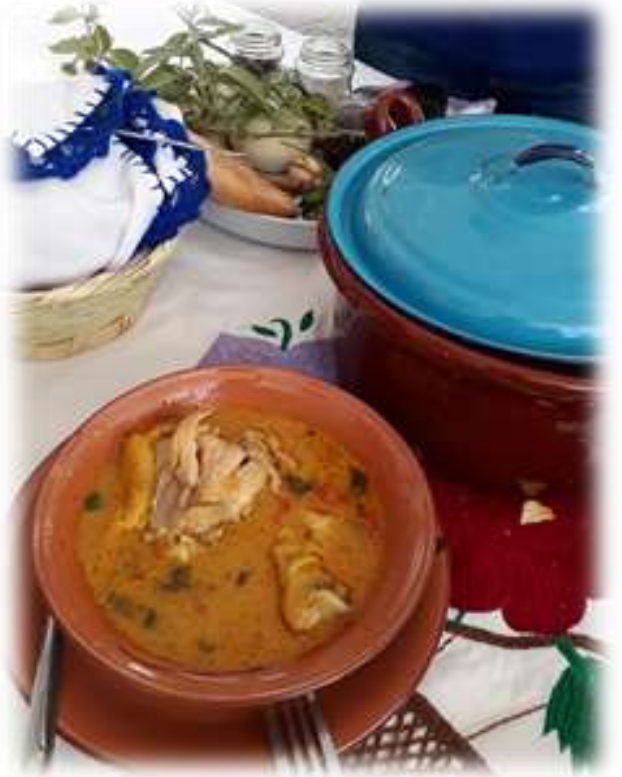

Photo 13 Pollo en Azafra: Nearby Tecozautla Hidalgo. There are the communities of Pañhé, Bomanxotha and la Mesilla where this dish is made as an offering to the deceased during the raising of the cross. La Azafra is a type of wild pepper found in the nearby hills. Photograph by José Armando Carrillo Silvano, 2018.

\section{Conclusions}

The state of Hidalgo has a broad culinary culture based on products from the surrounding fields that serve as a food source for most of the state's residents, that is why it is necessary to have strategies to promote, disseminate and commercialize it, although it is true that there are initiatives that support the communities such as "pueblos con sabor" (translated as towns with flavour), as well as the immense festivities and events held throughout the year, where the gastronomy promoted is not enough. That is why it is important to document it, because some species of animal origin such as Xincoyote or Squirrel, and plants such as maguey (cactus) from which the mixiote leaf is extracted, are protected, with that restriction some dishes that represent part of the identity of the Mexican people are lost, this is why it is important, at the moment, to work on strategies that allow to look after them, in order to re-establish their population, it is also suggested to reproduce this type of ethnographic work where the participation of academics, researchers, producers and servers in the food industry is promoted, to work togetherwith governmentand universities to impulse the culinary experience of the State of Hidalgo, which represents a great opportunity to know what is unknown about this field. Through fieldwork we conclude that the State of Hidalgo has a living gastronomy, that is transmitted orally from generation to generation and is usually not documented so over time, it will be unknown. Academics and cooks are interested in 
investigating remote communities that can perceive the risk of losing this heritage.

\section{References}

[1] Contreras, S. Lifeder.com. Obtenido de Lifeder.com: https://www.lifeder.com/historia-hidalgo/(1 de noviembre de 2017).

[2] Cervantes Cota, A. Historia y sabor de la cocina mexicana. Morelia. (2009).

[3] El universal. El universal. Obtenido de el universal: https://www.eluniversal.com.mx/destinos/los-5-pueblos-magicos-dehidalgo(4 de agosto de 2018).

[4] Pizarro Hernández, K., Granados Alcantar, J. A., Durán González, R. E., Nieto Estrada, E., Quezada Ramírez, M. F., Cortés Rivera, D., \& Castro Guzmán, M. "Ca tálogo de Pueblos y Comunida des Indígenas del Estado de Hidalgo". Pachuca de Soto.(2013).

[5] News Hidalgo. Obtenido de News Hidalgo: https://www.newshidalgo.com.mx/sectur-hidalgo-da-a-conocer-eldistintivo-pueblos-con-sabor/(12 de Julio de 2017).

[6] Trejo, L. E. El independiente. Obtenido del independiente: (25 de Julio de 2017). https://www.elindependiente

[7] Hernández, E. MILENIO. Obtenido de milenio: https://www.milenio.com/cultura/festejaran-pueblos-con-sabor-entulancingo (11 de diciembre de 2018).

dehidalgo.com.mx/van-15-municipios-distintivo-pueblos-sabor/

[8] Guerrero Arias, P. Guía etnográfica.Quito-Ecuador: Abya-Yala. (2002)

[9] Sánchez Martínez, D. V. Universidad Autónoma delEstado de Hidalgo. Obtenido de Universidad Autónoma del Estado de Hidalgo: (junio de 2014).

https://www.uaeh.edu.mx/docencia/P_Presentaciones/atotonilco_tula/i nteligencia_mercados/documentos/regiones_geo_culturales_de_hidalg o.pdf

\section{Annexed 1}

In the information below, there are some of the questions used during the investigation:

1. Could you mention a local holiday?

2. Could you mention a local product?

3. Do you believe that there is a representative community cuisine?

4. Could you mention the name of 5 dishes consumed in the community?

5. Could you mention 3 local dishes cooked in your family?

6. Could you mention a recipe that you consider exclusive for consumption by the population? Name the recipe.

(Does it have any other name?).

7. Does the dish have any historical, provenance or known antecedent?

8. Is it common to consume the dish daily or only when there is a celebration or holiday?

9. To end the interview: Do you know any dish that existed and is no longer consumed?

10. Do you know if any product is no longer consumed or has disappeared? 